How to Cite

Saidi, P. H., \& Mahyuni, L. P. (2020). Understanding the resistance against online transportation in a tourism

destination. International Journal of Business, Economics \& Management, 3(1), 55-60. https://doi.org/10.31295/ijbem.v3n1.125

\title{
Understanding the Resistance against Online Transportation in a Tourism Destination
}

\author{
Pilar Harmoni Saidi \\ Undiknas Graduate School, Denpasar, Indonesia \\ Email: pilarharmoni00@yahoo.com \\ Luh Putu Mahyuni \\ Universitas Pendidikan Nasional (Undiknas), Denpasar, Indonesia \\ Corresponding author email: mahyuniluhputu@undiknas.ac.id
}

\begin{abstract}
This paper offers an insight into the causes of resistance against online transportation in a tourist destination in Bali. Guided by the Theory of Planned Behaviour, this research collected data through interviews with the local transportation drivers and the chief of the local village. This paper indicates that the resistance against online transportation is mainly due to the perception that online transportation sets the below-the local standard price. This creates uneven business competition, inflict price war and destroy the transportation industry in the longrun. Mediation by the government is urgently needed to reach a win-win solution for the local and online transportation business.

Keywords---online transportation, resistance against online transportation, the theory of planned behaviour, tourism industry, transportation competition.
\end{abstract}

\section{Introduction}

Bali is one of the most famous tourism destinations in the world. The combination of beautiful sceneries and unique culture become a magnet to attract tourists from all over the world. As a major tourism destination, transportation is a vital support for accessibilities because the tourist movements are one of the most important element of tourism (Gross \& Klemmer, 2014). UNWTO defines tourism as a subset of travel since it entails the movement of people to countries or places outside their usual environment, for business and or leisure purposes. A transportation system consists of various physical facilities such as roads, bridges, drainage system, tunnels, traffic control and security devices, roadside tools, stop and transit stations, railroad, etc ( $\mathrm{Li}, 2019)$. Each facility has its own role to provide transportation service. The common method to transport people are using automotive (i.e. personal vehicles, taxi, ridesharing), transit (i.e. buses, trains, subways, ferry boats), air, two-wheeled vehicles (i.e. bicycles, motorcycles, scooter), and walking ( $\mathrm{Li}, 2019)$. Regardless of the method used, their core function is to provide safety and movement from the starting point to the destination.

The transportation industry develops rapidly along with technological advances. With the industrial revolution 4.0, the tourism industry becomes more accessible (Haque, 2015). It opens the previously inaccessible destinations and information. The revolution also spurred the innovation for transportation modes in the world. One of the results of the innovation is the online transportation. Online transportation is a business innovation which combined the transportation provider with internet-based technology (Anindhita et al., 2016). The other definition of online transportation is an individual transportation service where a customer can order or ride through mobile applications and the driver can respond the order through the apps (Silalahi et al., 2017). Some major advantages of online transportation are: (1) The customer and the driver can locate each other's exact position; (2) Customers obtain information about who will pick them and vehicle specification; (3) Customers can save a lot of time. Those advantages made online transportation quickly become popular, especially with the busy urban people. 
The presence of online transportation sparked conflict with the previously existed conventional transportation. Some countries banned them (Darto, 2016), for example Thailand's Ministry of Transportation ordered an online transportation organization to cease their operation and the Berlin authorities in Germany prohibits the online transportation because they didn't fulfil the safety standard. However, in some places in Indonesia, online transportation received a more violent reception. In Jakarta, there was a mass strike from the local transportation, which involved, violence, intimidation, and threat. BBC (Darto, 2016) reported that the local transportation protested the online transportation organization because they make it harder to get income. They also attacked and threatened whoever didn't join their cause. In Makassar, the local transportation raided online transportation vehicles and forced the passenger to drop off. This is caused by the perception that online transportation operated illegally (Anwar, 2017). The raid often ended up with violence and damage to the online transportation's vehicle, and the dropped passenger would have to walk on their own or hitch another vehicle. This is made worse by the seemingly slow response from the national government to solve the situation. Too many regulations, unclear instructions, lack of socialization, and overlapping issues.

The conflicts above can be seen as forms of resistance to change. Some of the reason for the resistance to change including no trusts towards the idea of change, no clear needs towards the change, the change threatens the economic importance of some people, the fear of personal failure, the loss of status and failure, against the ideal, and the anger towards the intervention (Darto, 2016). Resistance relates to an individual's will and acceptance towards a change, while it's also affected by mindset and behaviour. Each individual has their own defence method against the change, which also serves as the barrier for their adaptation (Fadzil et al., 2017). Resistance is also caused by the values that are accepted for a long time and difficult to change, so their believers tend to defend their belief and go against the change.

In the research area, the resistance against online transportation is presented by a lot of prohibition posters all around the place. There are also no online transportation operators sighted around the area, which strengthen the element of resistance (Ginaya et al., 2019). Therefore, this paper aims to understand and to explain the resistance against online transportation phenomenon in detail and more comprehensive by using the in-depth structured interview to the selected interviewees. The interviewees are mostly local drivers and one chief of the local village. The local transportation drivers are expected to provide insights about the reasons of their resistance against online transportation, and the chief of the local village is expected to provide an explanation about the local rules regarding the local and online transportation.

\section{Literature Review}

The Theory of Planned Behaviour is used in this research to guide data collection and data analysis processes. The Theory of Planned Behavior (TPB) was first introduced by Ajzen (1991). There are three predictors of person's behavioural intention: attitude towards an act or behaviour, the subjective norm, and perceived behavioural control. According to the TPB, when an individual is doing an act, they are not doing it with their free will, but instead someone or something is controlling them. The relationship between variables in TPB is drawn in Figure 1.

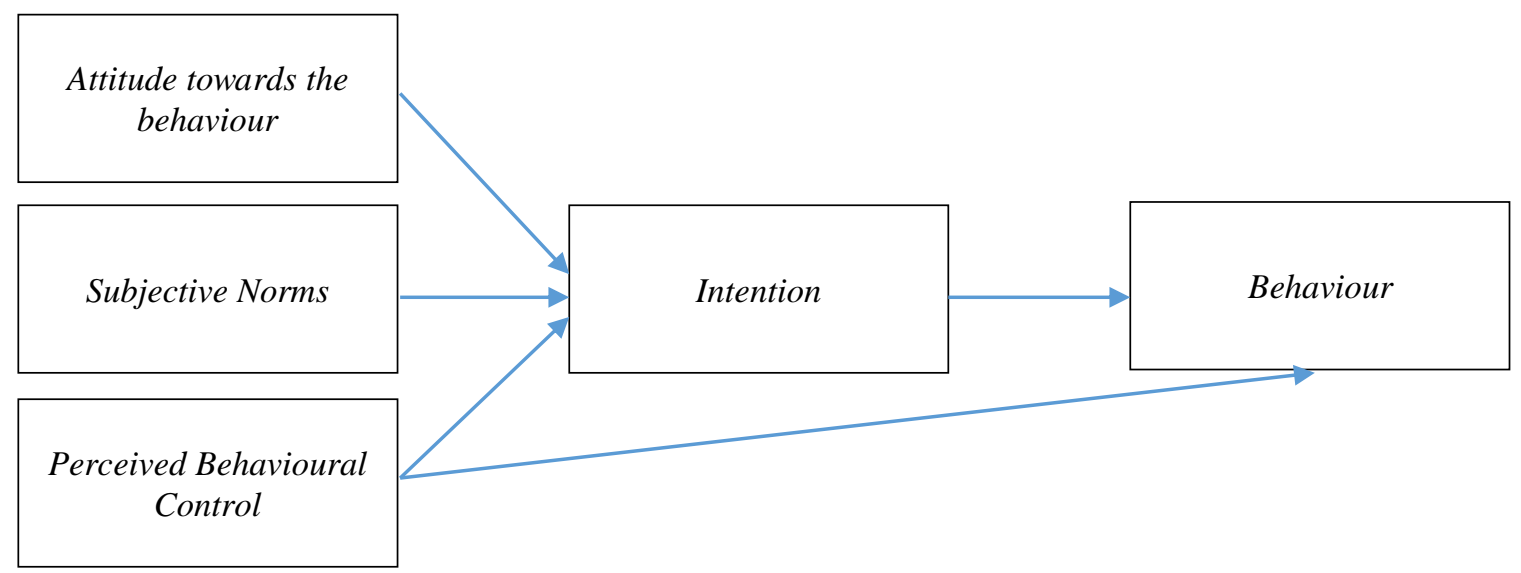

Figure 1. The theory of planned behaviour (Ajzen, 1991) 
Attitude towards behaviour is the result of an individual's belief towards a behaviour. Each individual has their own belief towards a behaviour. Each belief is related to an act which gives the result, and the result has a specific subjective value. The combination of the result and belief assumed to be able to produce an attitude towards a behaviour, whether it is positive or negative. Each subjective value or evaluation of the results contribute towards the attitude, which is directly proportional to someone's subjective probability which will produce the desired result (Ajzen, 2012).

Conceptually, the subjective norm is an independent attitude towards a behaviour. Principally, individuals can give a supportive attitude towards a behaviour, but feel the social pressure to not do that, and vice versa. In reality, the personal attitude and subjective norm rarely go fully orthogonal. This is because an event is highly possible to form parallel normative behaviour and belief (Ajzen, 2012).

Perceived Behavioural Control serves as the measure of how far an individual is confident that they can do a behaviour if they have the tendency to do it. Perceived Behavioural Control also affects behavioural performance indirectly through its influence towards the intention to do a behaviour and their perseverance to go through obstacles that might be present (Ajzen, 2012). There are two aspects that should be considered: How far an individual can control a behaviour (controllability) and how confident an individual can do a behaviour (selfefficacy).

Human behaviour is directed by three considerations: behavioural beliefs, normative beliefs, and control beliefs (Ajzen, 2012). When combined, the attitude towards behaviour, the subjective norms, and the perception of behavioural control will lead to the formation of the behavioural intention. The more supportive attitude and norms are given and the more controllable a behaviour, then the behavioural intention will also be stronger.

\section{Methodology}

To address the research questions, the phenomenology approach was used. Phenomenology approach is useful in observing a phenomenon from up close while also understanding the life experience from the participant's perspective (Qutoshi, 2018; Padilla-Díaz, 2015). Data were collected through in-depth-face-to-face interviews with seven interviewees, six of them are local transportation drivers and the rest is the local village chief. The duration of the interviews was between 30 to 60 minutes. The interviewees were guaranteed anonymity to encourage participation and to ensure that the interviewees could provide complete and honest information with comfort (Surmiak, 2018).

The interviewees were then assigned certain codes in the process of analysis and data presentation. The local transportation drivers are mentioned as D1, D2, D3, D4, D5, D6, while the village chief is given 'VC' code. The exact location of this study is also covered as requested by the interviewees. The anonymity of the interviewees and concealment of the exact location of this study are applied due to the phenomenon explored in this study is considered sensitive. The interviews were recorded and/ or noted and transcribed before analysed. Guided by the Theory of Planned Behaviour, several codes were identified from the interview transcripts. The codes were then collapsed into several themes. Several quotations were taken from the interview transcripts to support the analysis.

\section{Findings}

To apprehend the comprehensive and honest perspective of the interviewees, interviews were conducted as an informal and friendly conversation. In general, based on the results of the interviews, this research indicates that there are three major factors that explain resistance against online transportation in a tourism destination, namely: (1) attitude towards resistance against online transportation operation, (2) uneven business competition created by online transportation operation, (3) price factor. The three factors altogether explain intention to resist online transportation and implement the competitive strategy. The results of the interviews are depicted in Figure 2 and further discussed in the following subsections. 


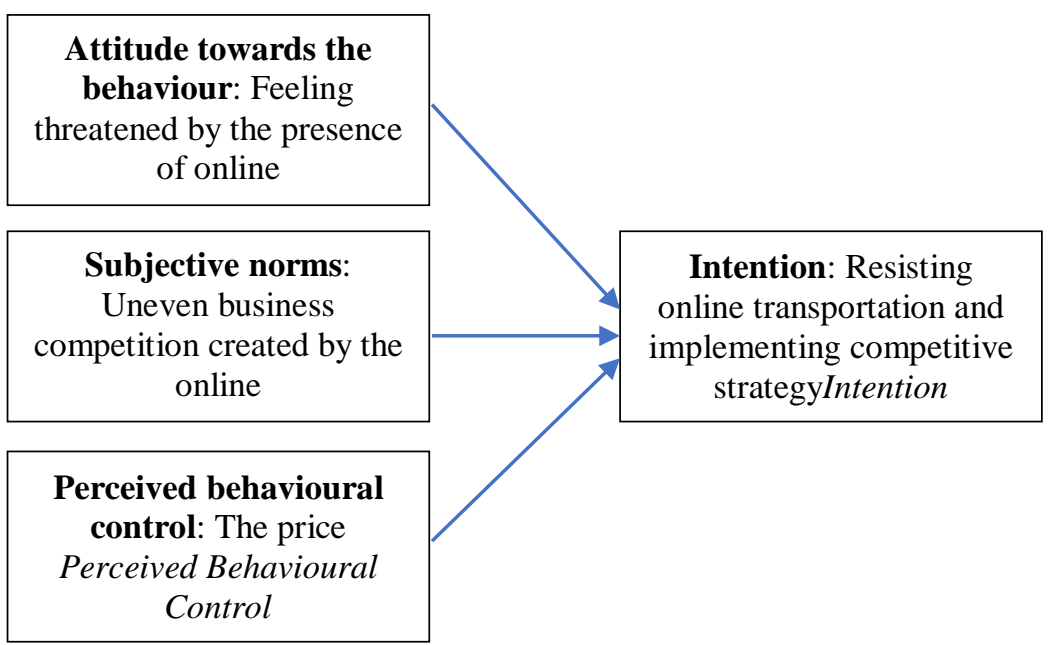

Figure 2. Factors explaining resistance against online transportation in a tourism destination

\section{Attitude towards the behaviour: feeling threatened by the presence of online transportation}

The majority of interviewees resist the operation of online transportation. They explained that the online transportation drivers offer lower prices, so as some of their customers prefer the online taxi. The presence of online transportation is considered as a threat by the interviewees, as explained by D2, "Yes, I am rejecting online transportation operated here. I am worried that they will take all of our customers". This statement is supported by $\mathrm{VC}$," online transportation is a serious threat for us. They ignore the local rules that regulate the operation of transportation for tourism in this area".

In general, the interviewees hold negative perceptions towards the presence of online transportation. This is the internal factor of the interviewees that drive them to resist online transportation.

\section{Subjective norms: uneven business competition created by the online transportation}

This research found that besides the internal factor of the interviewees, the resistance against online transportation is also driven by the external factor, an uneven business competition created by the online transportation. Most of the interviewees felt that the presence of online transportation creates uneven business competition because online transportation offers lower prices compared to local transportation. One of the interviewees stated, "Yes, I am resisting the online transportation here. It is because their price is way lower compared to the standard here. They are damaging the price (D2)."

Referring to five competitive forces (Harvard Business Review, 2008), the level of competition is determined by four factors: the presence of substitute products, new entrants, consumers' bargaining power, and suppliers' bargaining power. In this research, the online transportation is considered as the new entrant that offers lower prices. In the context where the consumers' bargaining power is relatively high, like in the context of this research, competing on price could be an effective strategy. However, some interviewees argued that transportation services that offer low prices could possibly sacrifice service quality. One of the interviewees stated,

"The local transportation drivers are all registered and monitored well, so as the safety of the customers and their belongings are guaranteed. In my opinion, this is not the case for online transportation drivers (D3)."

\section{Perceived behavioural control: the price}

This research indicates that the resistance against online transportation could be lower if the online transportation drivers are willing to adjust their price to the local standard, as mentioned by D2, "I actually don't mind competing with them. If they want to compete fairly, they must adjust their price, so it won't be much different than our price (D2)." Interviewee D3 added, "If the price is similar, why not? We are open to fair competition. It motivates us to continuously improve our service quality (D3)." 


\title{
Intention
}

Negative perceptions towards the presence of online transportation drive intention to resist online transportation and to implement the competitive strategy. Most of the interviewees stated that they have better knowledge and understanding about the local roads, rules, customs and culture compared to the online transportation drivers. This could be an important selling point. Interviewee D4 explained,

\begin{abstract}
"Safety is utmost important in the transportation industry. When it comes to providing transportation services for the tourists, delivering correct and complete information regarding local norms, rules and culture are also very important. The guests often ask about Balinese life and culture. So, I think in terms of knowledge about the local culture, we are much better than the online transportation drivers (D4)."
\end{abstract}

The local transportation businesses also set standard operating procedures (SOP) to ensure the service quality standard can be met by all drivers. One of the standards is the drivers have to be registered in the system, so as they can be monitored easily, as explained by D3, "We have our own SOP. If a driver pick-up a guest, we can easily identify the driver. It is very important to ensure that the guests we pick-up arrive safely (D3)."

Negotiable price is also the strategy used by the local transportation drivers to remain competitive. The price is flexible because the local transportations are not bound to the applications. Interviewee D5 stated, "We informed the guests that our price is negotiable, not bound to the applications like online transportation (D5)."

\section{Discussion}

The resistance against online transportation can also be found in other countries like Thailand, Germany and the Netherlands. Thailand orders an online transportation organization to cease its operation. In Germany, online transportation is prohibited because they do not fulfil the safety standard, and they are considered illegal. In the Netherlands, the online transportation is prohibited because they are considered to break the rules about drivers (Darto, 2016).

In Indonesia, the resistance can also be found in other provinces, like in Makassar and Jakarta. The major concerns that drive the resistance are the operational permit, plate license, pick up locations and price wars (Anwar, 2017). Another concern about online transportation is that they are considered illegal and potentially killing local transportation businesses (Amelia, 2016).

The online transportation was first introduced to address the problem of disappointing public transportations condition. This provides inspiration for the IT companies to follow up the market's request which is completely unexpected (Amelia, 2016). However, in the context of tourism destination where many locals earn a living from running a transportation business for tourists, the presence of online transportation is perceived as a threat to local businesses.

This research found that the resistance against online transportation arises from fear or doubt to adapt to the change. The resistance is related to a certain person's readiness and will to adapt, which is affected by their thought and behaviour (Fadzil et al., 2017).

The government's role is needed as a mediator to mediate the conflict between local and online transportation (Darto, 2016). Besides that, to remain competitive, the local transportation business needs to adapt to the current technology. Since there is a growing interest of tourists to prefer online transportation (Pratiwi \& Kesumadewi, 2017). The local transportation business may consider to develop their own application or collaborate with online transportation.

\section{Conclusions}

This paper concludes that the resistance against online transportation in tourism destination in Bali is due to the perception that online transportation creates uneven business competition by setting the below-the standard price. In a price-sensitive industry, like in the context of this study, a price war will result in lower service quality and destroy the industry in the long-run. Mediation is needed between the local and online transportation business to reach a winwin solution that will benefit the transportation industry in the long-run. 


\section{References}

Ajzen, I. (1991). The theory of planned behavior. Organizational behavior and human decision processes, 50(2), 179-211.

Ajzen, I. (2012). The theory of planned behavior. Handbook of Theories of Social Psychology: 1, 438-459. https://doi.org/10.4135/9781446249215.n22

Amelia, L. (2016). Respon Kebijakan Terhadap Transportasi Berbasis Aplikasi di Jakarta. The Indonesian Institute.

Anindhita, W., Arisanty, M., \& Rahmawati, D. (2016). Analisis Penerapan Teknologi Komunikasi Tepat Guna Pada Bisnis Transportasi Ojek Online (Studi pada Bisnis Gojek dan Grab Bike dalam Penggunaan Teknologi Komuniasi Tepat Guna untuk Mengembangkan Bisnis Transportasi). In Prosiding Seminar Nasional INDOCOMPAC.

Anwar, A. A. (2017). Online vs konvensional: keunggulan dan konflik antar moda transportasi di kota makassar. ETNOSIA: Jurnal Etnografi Indonesia, 2(2), 220-246. http://dx.doi.org/10.31947/etnosia.v2i2.3012

Darto, M. (2016). Smart Government: Berdamai dengan Perubahan. Jurnal Borneo Administrator, 12(1), 1-7.

Fadzil, S., Syed Mohamad, S. J. A. N., \& Hassan, R. (2017). Resistance to Change (RTC): A Taxonomical Perspective. Journal of Management and Marketing Review (JMMR) Vol, 2(3).

Ginaya, G., Sudarmini, N. M., \& Damayanti, I. K. W. (2019). Tri hita karana and sad kertih values in Belimbing rural tourism development. International Journal of Social Sciences and Humanities, 3(2), 10-23. https://doi.org/10.29332/ijssh.v3n2.282

Gross, S., \& Klemmer, L. (2014). Introduction to tourism transport. CABI.

Haque, Z. (2015). The impact of economic crisis on tourism industry. International Research Journal of Engineering, IT \& Scientific Research, 1(1), 12-23.

Harvard Business Review. (2008). HBR's Must-Reads on Strategy. Harvard Business Review, 86(12), 143. https://doi.org/10.1111/j.0955-6419.2005.00347.x

Li, Z. (2018). Transportation Asset Management: Methodology and Applications. CRC Press.

Padilla-Díaz, M. (2015). Phenomenology in educational qualitative research: Philosophy as science or philosophical science. International Journal of Educational Excellence, 1(2), 101-110.

Pratiwi, A. M., Kesumadewi, P. D., Par, S. S. T., \& Par, M. (2017). Keberadaan transportasi online dalam industri pariwisata bali.

Qutoshi, S. B. (2018). Phenomenology: A philosophy and method of inquiry. Journal of Education and Educational Development, 5(1), 215-222. http://dx.doi.org/10.22555/joeed.v5i1.2154

Silalahi, S. L. B., Handayani, P. W., \& Munajat, Q. (2017). Service quality analysis for online transportation services: Case study of GO-JEK. Procedia Computer Science, 124, 487-495. https://doi.org/10.1016/j.procs.2017.12.181

Surmiak, A. D. (2018, September). Confidentiality in qualitative research involving vulnerable participants: Researchers' perspectives. In Forum Qualitative Sozialforschung/Forum: Qualitative Social Research (Vol. 19, No. 3). http://dx.doi.org/10.17169/fqs-19.3.3099 